\title{
Ecology and management of invasive Pinaceae around the world: progress and challenges
}

\author{
Martin A. Nuñez $\mathbb{D}$ - Mariana C. Chiuffo - Agostina Torres - Thomas Paul • \\ Romina D. Dimarco - Peter Raal • Nahuel Policelli · Jaime Moyano • \\ Rafael A. García · Brian W. van Wilgen · Aníbal Pauchard • David M. Richardson
}

Received: 4 October 2016/ Accepted: 15 June 2017

(C) Springer International Publishing AG 2017

\begin{abstract}
Many species in the family Pinaceae are invaders. These species are relatively easy to control because of some of their intrinsic characteristics and because they are highly visible and easy to eliminate. Many Pinaceae species have been well studied because of their use in forestry and their invasive behavior in many countries. The impacts of invasive Pinaceae are not only ecological, but also economic and social. We review the ecology and management of Pinaceae invasions and explore how restoration of
\end{abstract}

Guest Editors: Andrew Liebhold, Eckehard Brockerhoff and Martin Nuñez / Special issue on Biological Invasions in Forests prepared by a task force of the International Union of Forest Research Organizations (IUFRO).

M. A. Nuñez $(\bowtie) \cdot$ M. C. Chiuffo · A. Torres ·

N. Policelli · J. Moyano

Grupo de Ecología de Invasiones, INIBIOMA,

CONICET-Universidad Nacional del Comahue, Av. de

Los Pioneros 2350, 8400 Bariloche, Argentina

e-mail: nunezm@gmail.com

T. Paul

New Zealand Forest Research Institute Ltd, 49 Sala

Street, Private Bag 3020, Rotorua 3046, New Zealand

R. D. Dimarco

Grupo de Ecología de Poblaciones de Insectos,

CONICET, INTA, Modesta Victoria 4450,

8400 Bariloche, Argentina

P. Raal

Department of Conservation, Dunedin Office,

P O Box 5244, Dunedin 9016, New Zealand invaded areas should be addressed. There are many ways to prevent invasions and to deal with them. Planting less invasive species, better site selection, and invasion monitoring are used successfully in different parts of the world to prevent invasion. Mechanical and chemical methods are used effectively to control Pinaceae invasions. Control is more effective at the early stages of invasion. Old invasions are more problematic as their elimination is more expensive, and the restoration of native vegetation is challenging. In some areas, native vegetation cannot thrive after Pinaceae have been removed, and weeds colonize cleared areas. More attention is needed to prevent the initiation and spread of invasions by focusing control

\author{
R. A. García - A. Pauchard \\ Laboratorio de Invasiones Biológicas, Facultad de \\ Ciencias Forestales, Universidad de Concepción, Casilla \\ 160-C, Concepción, Chile \\ R. A. García - A. Pauchard \\ Institute of Ecology and Biodiversity (IEB), Las Palmeras \\ 3425, Santiago, Chile \\ B. W. van Wilgen - D. M. Richardson \\ Centre for Invasion Biology, Department of Botany and \\ Zoology, Stellenbosch University, Stellenbosch, South \\ Africa
}


interventions at early stages of invasion. Finding new ways of dealing sustainably with conflicts of interest between foresters and conservationists is crucial. Nonnative Pinaceae are important parts of the economies and landscapes in several countries and they will continue to play such a role in the future. Despite the numerous challenges facing Pinaceae invasion management, several approaches can be successful at controlling them. Proper application of current techniques and development of more efficient ones is needed if the goal of maximizing benefits and minimizing negative impacts is to be achieved.

Keywords Impacts $\cdot$ Herbicides $\cdot$ Management . Pinus · Restoration · Southern Hemisphere - Tree invasions

\section{Introduction}

Managing invasive species to reduce their impacts on biodiversity and ecosystems services is a major challenge. Considerable resources are allocated to manage invasions in many parts of the world, often with limited success. Some invasive species are notably difficult to control, such as microbial species, animals such as mice or pigs, or plants that produce very large numbers of seeds, accumulate large longlived seed banks in the soil, can resprout vigorously, or have early onset of reproduction (e.g. Richardson and Kluge 2008; Wilson et al. 2011; García et al. 2015; Dickie et al. 2016). However, there are other invasive organisms with biological characteristics (e.g. later onset of reproduction, site specificity) that make them easier to control, at least when they occur at low densities over small areas.

Invasive Pinaceae species (members of the pine family) that establish from self-sown seeds in areas where they are unwanted are transformative species that invade large areas outside their native range, especially in the Southern Hemisphere (Richardson and Higgins 1998). Such invasions change the functioning of ecosystems, affect the provision of certain services, and restrict options for land use (Simberloff et al. 2010). This is particularly problematic when pines invade systems where trees were previously rare or absent, such as natural shrublands and grasslands (Rundel et al. 2014; Pauchard et al. 2016).

Pinaceae invasions have major ecological and economic impacts. Impacts on water resources in South Africa are probably the best-studied example (e.g. Le Maitre et al. 2002). Pinaceae invasions also have important social and cultural implications (Greenaway et al. 2015) and have negative effects on ecosystem services (Dickie et al. 2014a). For example, an economic assessment in New Zealand quantified the negative impacts of invasive conifers on farm productivity, tourism, rare species conservation and water availability at over a billion NZ\$ over the next 20 years (Velarde et al. 2015). Invasive Pinaceae also transform historic landscapes by having detrimental effects on values related to landscape features of cultural importance, such as sacred mountain tops and historical sheep-grazing country (Greenaway et al. 2015).

In contrast to many other invasive tree species, invasive Pinaceae species are relatively easy to control especially when they occur at low densities (less than 100 trees per hectare) and are of smaller size (e.g. seedlings and saplings). None of the most widespread invasive Pinaceae species resprout after felling, none have long-lived seeds that accumulate in the soil, and seedlings can easily be hand-pulled (Ledgard 2001, 2009b). It takes them years to start producing viable seeds (more than seven years for most invasive Pinaceae species, and more than 15 for others). Their seeds are dispersed by wind, which is more predictable than some other forms of seed dispersal, such as dispersal by birds (Buckley et al. 2006). Moreover, because pines are important forestry species, key aspects of their biology and ecology have been well studied (e.g. Richardson 1998a; Richardson and Higgins 1998).

In the last few decades, numerous studies have investigated the invasion ecology of most of the invasive Pinaceae species (Richardson and Higgins 1998; Richardson 2006; Essl et al. 2011; and references therein) and in some countries economic incentives and legal instruments are in place to prevent and manage current and future invasions (van Wilgen and Richardson 2012; MPI 2014). Pines are well-known and conspicuous invasive species, and conservation organizations are concerned about them. Nonetheless, invasive pines remain a huge and growing problem in areas with a long history of 
afforestation of non-native pine plantations, and are an emerging problem in areas with a shorter history of exposure to non-native pine plantation forestry (Richardson et al. 2008). Pinaceae invasions occur predominantly in the Southern Hemisphere. In the Northern Hemisphere, the lower introduction effort of non-native Pinaceae and other factors such as the widespread presence of pathogens adapted to native species in the family, have been proposed as causes for the low levels or even absence of invasions (Simberloff et al. 2010; Essl et al. 2011; McGregor et al. 2012; Rejmánek and Richardson 2013).

Pine invasions in the Southern Hemisphere are difficult to manage, for a number of reasons. These include the fact that the invaded areas have become quite large, and are often in rugged and inaccessible terrain; the difficulties of assigning responsibility for their management when pines escape from plantations and invade adjacent areas (McConnachie et al. 2015); and the fact that the trees themselves have value in certain contexts, but not in others, leading to conflicting views on the goals of management (Dickie et al. 2014a; Woodford et al. 2016; Zengeya et al. 2017). Nonetheless, advances are being made in different parts of the world regarding all the issues mentioned above. This paper provides a global overview of the ecology of Pinaceae invasions, reviews the techniques that have been used to control their spread, and explores how restoration of invaded areas should be addressed.

Pine ecology from a biological invasions perspective

Because of their importance as commercial forestry crops and their widespread use as ornamental plants and amenity trees, many of the more than 200 species of Pinaceae have been widely disseminated around the world (Procheş et al. 2008, 2012; Essl et al. 2010; Simberloff et al. 2010; Pauchard et al. 2015). Many species of Pinus and other genera in the family Pinaceae have been very widely planted outside their natural ranges all around the world and a number of species have escaped plantations and established in new ranges (Ledgard 2001; Richardson and Rejmánek 2004; Richardson et al. 2008; Essl et al. 2010; Rejmánek and Richardson 2013). Non-native pine invasions are most widespread in the Southern Hemisphere (Richardson and Higgins 1998). However, not all important forestry Pinaceae species have succeeded in invading new ranges (Richardson and Higgins 1998).

To invade a new area, species must overcome abiotic and biotic barriers. Among the abiotic barriers, climate is an important factor determining invasion success in Pinaceae species (Nuñez and Medley 2011). Even though appropriate climatic conditions per se are required for Pinaceae to invade, in practice the importance of this filter is reduced because foresters have tended to use provenances of pine species that are well adapted to the local climates in new environments (Zenni et al. 2014; Pauchard et al. 2015). Consistently, invasion patterns show a strong match between broad climatic zones in native and invaded ranges-i.e. tropical Pinaceae are invasive in tropical regions, subtropical and temperate Pinaceae species invade in subtropical and temperate zones (Pauchard et al. 2015). Interestingly, in some cases climate in the introduced range is more favorable for growth and reproduction of a species, which can lead to higher rates of establishment and higher invasion densities (Taylor et al. 2016).

Many Pinaceae species have a fairly wide edaphic tolerance and can grow well in nutrient-poor soils (Richardson and Higgins 1998; Pauchard et al. 2015); soil requirements are therefore generally not a key mediator of Pinaceae invasions, but rather allow Pinaceae invasions on eroded sites with reduced vegetation competition (Ledgard 2004). In fire-prone systems, fire events can trigger the invasion of those Pinaceae species that are adapted to fire (Richardson et al. 1990). In general, the environmental factors that prevent or facilitate invasions are quite predictable but other factors may be present that ultimately determine Pinaceae invasion success or failure, such as biotic interactions.

Biotic interactions can both hinder or promote Pinaceae invasions. Among the biotic interactions that may retard Pinaceae invasion, post-dispersal seed predation by rodents and granivorous birds is important in limiting the establishment of pine trees in uninvaded areas (Caccia and Ballaré 1998; Nuñez et al. 2008b). Seedling herbivory is another important factor limiting Pinaceae invasions (Benecke 1967; Richardson et al. 1994; Ledgard 2001; Becerra and Bustamante 2008). Although low or high levels of herbivore pressure potentially control the invasion of pines, intermediate levels promote invasibility 
(Richardson and Bond 1991; Richardson et al. 1994). There is evidence that the preference of herbivores for native trees could also facilitate invasion by nonnative Pinaceae (Nuñez et al. 2008a; Relva et al. 2010). It has also been suggested that Pinaceae trees have a lower pathogen load in non-native than in their native ranges (Wingfield et al. 2001; Crous et al. 2016), but the importance of this factor in mediating invasions has yet to be demonstrated (see Crous et al. 2016 for discussion). How competition (for light and water mainly) affects Pinaceae invasion also remains unclear (Simberloff et al. 2002). For instance, dense forest communities are rarely colonized by invading Pinaceae species (Richardson et al. 1994; Higgins and Richardson 1998; Simberloff et al. 2002) but invasions of non-native Pinaceae species do occur in some forest communities (Ledgard 2002; Dehlin et al. 2008). Where shade-intolerant Pinaceae species do not establish, low light availability and competition with other plants are potential limiting factors (Davis et al. 1996; Simberloff et al. 2002; Adamowski 2004). When comparing the influence of biotic factors for one invasive pine (Pinus contorta) between their native and their introduced ranges, biotic resistance to invasion is more important in the introduced range where areas of high plant cover are consistently more resistant to invasion than in the native range (Taylor et al. 2016).

Belowground mutualists, particularly ectomycorrhizal fungi (EMF), play a key role in mediating Pinaceae invasions (Richardson et al. 2000; Nuñez et al. 2009; Pringle et al. 2009; Dickie et al. 2010). EMF improve the acquisition of nutrients and water, and provide protection from antagonists to the plant, in exchange for sugars derived from photosynthesis (Smith and Read 2008). For invasive species in general, being facultatively mycorrhizal is considered beneficial, as the flexibility of this mycorrhizal status allows plants to use a broader set of ecological strategies to assure spread (Menzel et al. 2017). Pinaceae species are obligately ectomycorrhizal and show low growth and survivorship in the absence of this form of symbiosis (Mikola 1970; Nuñez et al. 2009). The absence of specific ectomycorrhizal symbionts hinders Pinaceae invasion, and species tend to co-invade with their EMF as shown in New Zealand by Dickie et al. (2010). In the invaded range, fungi and trees disperse independently but the successful establishment of new seedlings requires the presence of fungal inoculum (Nuñez et al. 2009; Pringle et al. 2009).

Only a small portion of the ectomycorrhizal fungi species present in the native range are found in the invaded range (Dickie et al. 2010; Gundale et al. 2016). Although this pattern has been suggested to be a result of incomplete co-introductions, there is evidence that the mechanism could also be due to additional geographic or local factors (Gundale et al. 2016). Hayward et al. (2015b) showed that only one EMF (Suillus luteus) was necessary to facilitate Pinaceae invasions, even in the absence of other effective co-invasive EMF. Different traits among EMF such as competition ability, dispersal and spore production make some of them more invasive than others (Dickie and Reich 2005; Ashkannejhad and Horton 2006; Hayward et al. 2015a). Nuñez and Dickie (2014) proposed the possibility of identifying and inoculating EMF species that are both useful in forestry and have a low invasion risk, as a way of improving the environmental sustainability of plantation forestry with non-native tree species such as pines.

Biotic interactions cannot be considered separately when seeking explanations for the success or failure of Pinaceae invasions. Non-indigenous mammals, for example, prefer browsing native tree species which potentially compete with Pinaceae species (Nuñez et al. 2008a; Relva et al. 2010) and also disperse invasive EMF spores (Nuñez et al. 2013; Wood et al. 2015). This complex web of biotic interactions involving three invasive organisms (invasive mammals, invasive EMF and invasive plants) facilitates the co-invasion of Pinaceae species and their associated belowground mutualists (Nuñez et al. 2013; Wood et al. 2015). The identification of multiple interactions could be crucial in predicting invasions and mitigating their impacts (Wood et al. 2015).

Prediction of Pinaceae invasions

Predicting Pinaceae invasions should be more straightforward than for many other groups of invasive species. Pinus, the largest genus of Pinaceae, has been proposed as a model taxon for advancing the field of invasion science (Richardson 2006; Kueffer et al. 2013; Gundale et al. 2014).

Much information is available on the characteristics of Pinaceae species that enhance invasiveness. 
Rejmánek and Richardson (1996) developed a discriminant function ( $\mathrm{Z}$ score) based on simple traits (seed mass, juvenile period, and intervals between large seed crops) that successfully separated invasive from non-invasive Pinus species. This function has been successfully applied to other conifer taxa (Richardson and Rejmánek 2004). Highly invasive Pinaceae species have a low seed mass and a large wing-area, features related to a higher dispersal capacity (Siggins 1933; Sharpe and Fields 1982) of seeds by wind (Rejmánek et al. 2013). Further research has revealed that small seed mass is associated with high relative growth rates of seedlings, which in turn contributes to strong competitive ability in seedlings and, therefore, the capacity to perpetuate without human assistance (Grotkopp et al. 2002). The other two key traits found by Rejmánek and Richardson (1996) also have important implications for their success as invaders. Short juvenile periods mean that seed production starts at an early age, and short intervals between large seed crops in highly invasive pine species means continuous seed production. Both traits contribute to a high reproductive capacity that favors population growth and increases invasion potential (Rejmánek 1996). According to the Z score, Pinus contorta, $P$. halepensis, $P$. pinaster and $P$. radiata are among the most invasive Pinaceae species, which is consistent with evidence from around the world (Richardson et al. 1990, 1994; Ledgard 2001; Simberloff et al. 2010; Richardson and Rejmánek 2011; Rejmánek and Richardson 2013; Taylor et al. 2016).

Human factors are key mediators of the invasion success of Pinaceae taxa. Introductions of Pinaceae species were historically focused on a group of species with traits suitable for different forms of forestryfeatures that are, however, also positively correlated with invasiveness of a species (Richardson 1998b). This bias in the pool of introduced species has, therefore, influenced the outcome of Pinaceae introductions (McGregor et al. 2012). Propagule pressure is also a key driver of invasion success among Pinaceae species (Procheş et al. 2008; Essl et al. 2010; Hulme 2012; McGregor et al. 2012; Pauchard et al. 2016). Species planted over large areas for several decades have a higher probability of escaping from plantation than species with more recent plantings.

Ecosystem characteristics also influence Pinaceae invasions and must be considered when assessing the risk of invasions from plantations. Naturally open ecosystems, such as grasslands and shrublands, are much more frequently invaded by Pinaceae species than tree dominated vegetation (Richardson et al. 1994; Rundel et al. 2014; Taylor et al. 2016). This is because most of the pine species introduced to other regions are shade intolerant (Minore 1979; Lotan and Perry 1983; Burns and Honkala 1990). Richardson and Bond (1991) described a gradient of decreasing habitat invasibility starting with natural and semi-natural grasslands as the most prone to invasion, followed by shrublands, open woodlands, with forests being the most resistant. Even when forests are considered resistant to Pinaceae invasions (Richardson et al. 1990; Ledgard 2001; Langdon et al. 2010), there are species that invade these types of environments. Pseudotsuga menziesii, which is shade-tolerant during its first years (Minore 1979; Hermann and Lavender 1990), is a key example of a species that invades forests (Ledgard 2002; Simberloff et al. 2002; Peña et al. 2007; Dehlin et al. 2008).

Disturbance is another factor that strongly influences Pinaceae invasions. Independently of ecosystem type, disturbances in general promote Pinaceae invasions (Richardson and Bond 1991; Grotkopp et al. 2002) reducing the competition with other plant species and releasing resources (Rejmánek 1989). For instance, Richardson et al. (1994) showed that disturbance events such as grazing, mechanical clearing, fire or flooding could enhance the likelihood of pine establishment, mainly because they reduce biotic resistance to invasion (Richardson and Higgins 1998). There is thus, a high probability of Pinaceae invasion in open or disturbed habitats if a seed source exists. Features of the disturbance regime, together with other ecosystem properties and species traits, are important for predicting the invasion dynamics of Pinaceae species. The relative importance of each of these factors varies between sites, since some ecosystems are more prone to invasion without human-mediated disturbance than others.

\section{Prevention of pine invasions}

There are several ways to prevent or reduce the likelihood of Pinaceae invasions. One option is to choose less invasive species. This is not always practical because regional and international forestry markets are firmly focused on a small number of tree 
species, the most desirable of which are all invasive. Other proposed options are to improve the site selection for plantations to reduce the risk of their dispersal from the plantations (Ledgard and Langer 1999), to improve plantation management and silvicultural practices (Greene et al. 2002; Bohrer et al. 2008), and to reduce seed dispersal and/or seedling establishment beyond plantation boundaries. Forestry companies worldwide are under pressure to manage pine plantations more sustainably and to reduce impacts caused by seed dispersal from plantations on land outside areas allocated for forestry. Worldwide certification schemes for the sustainable management of forests and plantations (e.g. Forest Stewardship Council) and the inclusion of prevention measures in governmental initiatives in several countries are examples for this trend. In New Zealand the Wilding Conifer Management Strategy (MPI 2014) and the National Environmental Standards for Forestry include requirements to reduce the future risk of seed pollution. In South Africa, the Regulations promulgated under the National Environmental Management: Biodiversity Act allow for binding conditions to be prescribed for the cultivation of invasive species with commercial importance (van Wilgen and Richardson 2012). These conditions vary depending on the species concerned, but they typically require permit-holders to take steps to prevent spread, and can hold them responsible for the costs of control if the species does spread beyond the area for which a planting permit was issued.

A problem that complicates the management of pine invasions in some regions is that current invasions are attributable to diverse historical activities. This often results in confusion regarding the source of invasions (McConnachie et al. 2015), the responsibility for managing invasions, and the measures required to halt or reduce the risk of future invasions. Old plantations that contribute to current invasions are the result of inappropriate past practices that represent a serious challenge for current land managers. In New Zealand, for instance, a new non-statutory strategy to manage invasive Pinaceae in the future proposes to share responsibilities (MPI 2014).

Different approaches are used for managing invasions. In the Western Cape of South Africa, where pine invasions predate the establishment of organized commercial forestry (van Wilgen et al. 2016a), advanced statistical modeling has been applied to determine the proportion of the current extent of invasive populations attributable to forestry plantations (McConnachie et al. 2016). Such advances are helping to achieve a more objective framing of the drivers of such invasions, and therefore the responsibilities of different stakeholders (Woodford et al. 2016).

The rich literature on Pinaceae introductions, invasions and management of their invasions provides a robust framework for assessing the risk of invasions in areas where new forestry operations are planned or where afforestation is fairly recent, and where invasions may not have had time to manifest (Richardson et al. 2008; Simberloff et al. 2010). Many Pinaceae species have residence times of more than a century in many countries, and it was the goal of foresters in different areas to test numerous tree species from different regions. All species with major potential for use in forestry have already been widely tested and this has provided numerous opportunities for the species to "sample" potentially invasible sites. Therefore, it is very unlikely that species other than the currently known invasive Pinaceae will become major invaders in the future, although some surprises are possible. The development of new hybrids, climate change, and human-mediated changes to disturbance regimes may well lead to naturalization and even invasions of additional taxa. However, pre- and at-border screening is not as important in the overall strategy for managing Pinaceae invasions as it is with many other plant groups, because the global "introduction/invasion experiment" has already played out to a very large extent and the determinants of invasiveness are well understood at the species level. However, new genotypes of Pinaceae are being introduced, and developed using biotechnology, and screening at the level of genotypes may be warranted.

\section{Controlling Pinaceae invasions: learning from experience}

Some countries have had a longer history of Pinaceae control than others, having deployed substantial resources to manage invasive Pinaceae. New Zealand and South Africa are the two countries with the most experience in addressing Pinaceae invasions. Both countries have national legislation and strategies in place to reduce the current extent of invasions and to prevent future invasions (Simberloff et al. 2010; van 
Wilgen and Richardson 2012; MPI 2014). Due to the Pinaceae species involved, features of the invaded ecosystems, and markedly different socio-political contexts, very different management approaches have been used in the two countries (Fig. 1).

Managing Pinaceae invasions in New Zealand In New Zealand, pines were introduced and planted over very large areas in the mid-twentieth century (Ledgard 2001) and now cover $6 \%$ of the country's land area (Anon 2014b). Highly invasive pines such as $P$. contorta and $P$. nigra quickly became invasive in semi-natural grassland and open shrublands (Ledgard 2001; McGregor et al. 2012). By the end of the twentieth century, pine invasions had become a major economic and environmental nuisance over large parts of New Zealand (Ledgard 2004). The control of invasive pines with various means has been the subject
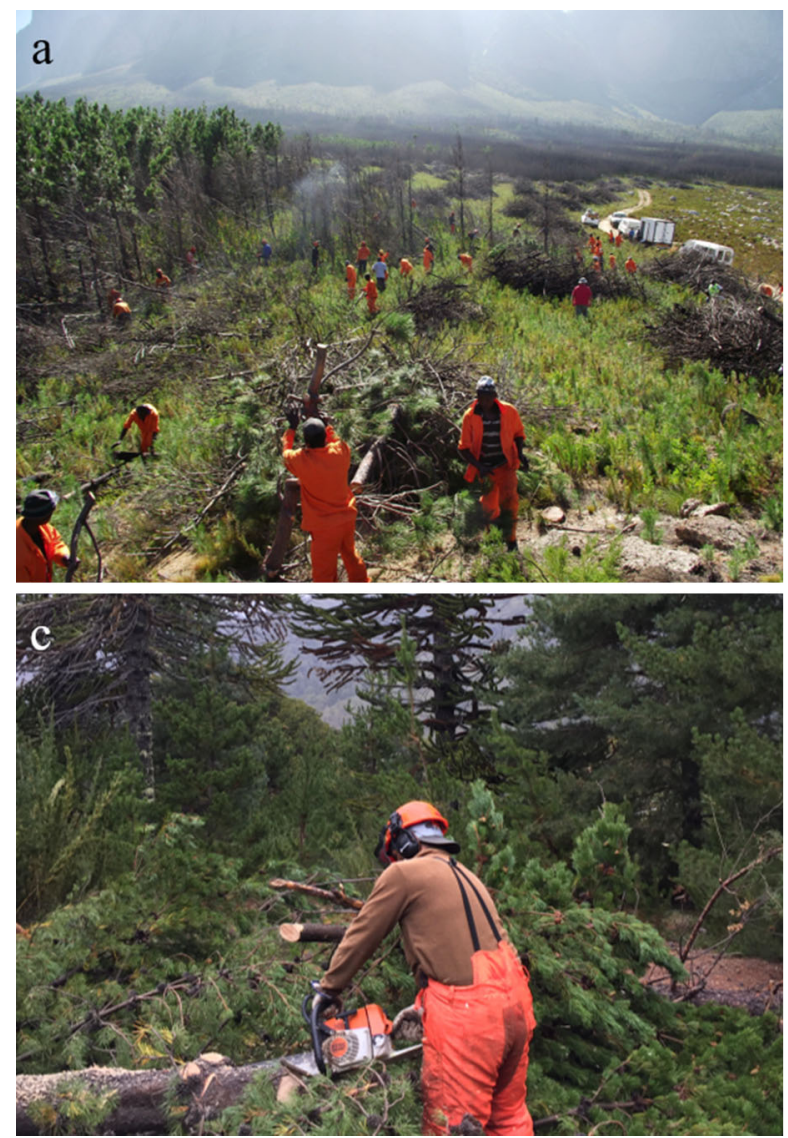

Fig. 1 Different control methods of invasive Pinaceae: a manual control of pines in South Africa (Photo J. van Rensburg); b control by fire in South Africa (Photo J. van Rensburg); of research over the last few decades in New Zealand, and protocols and manuals for management are available (Ledgard 2009a, b). The practical approach to control pines depends mostly on the size of the tree, the density of trees, and the terrain of the invaded area; these variables together influence the cost efficiency and practical feasibility of invasive pine control (Ledgard 2009b). Initial assessments of the nature and structure of the invasion are therefore important. Also, to be more efficient in achieving good control, improved monitoring and survey systems are needed (Maxwell et al. 2009; Wilson et al. 2014).

Mechanical control was the standard for many years and mechanical means (pulling or cutting) are still commonly used, particularly in easily accessible areas with low densities of small and medium-sized trees (100 trees per hectare or less; tree size up to $20 \mathrm{~cm}$ in stem diameter and less than $5 \mathrm{~m}$ tall). For all
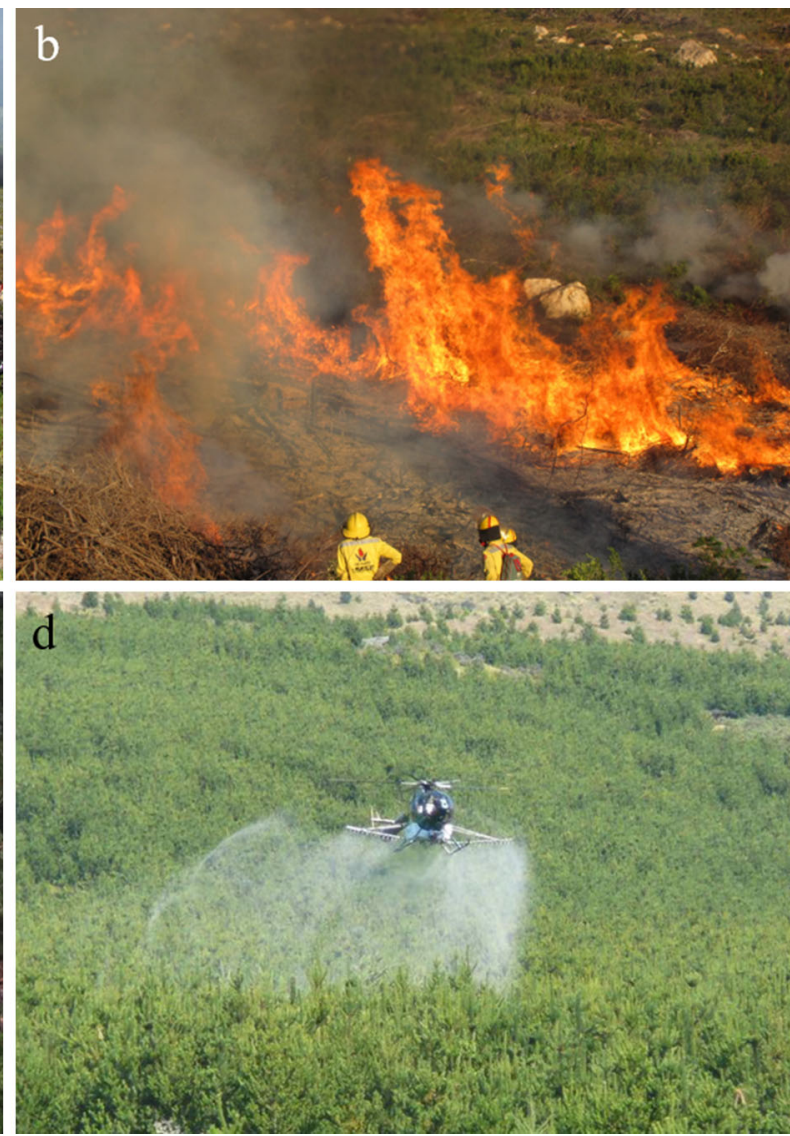

c mechanical control in Chile (Photo LIB University of Concepcion); and $\mathbf{d}$ chemical control in New Zealand (Photo P. Raal) 
mechanical methods, probably the critical factor is the ability to access the target tree. Mechanical control of pine trees requires a high level of diligence to be successful. All invasive pines need to be cleared from a site and all green foliage (when trees are felled or cut) must be removed, or trees need to be completely removed from the soil (when hand pulled) to avoid regrowth, particularly with species such as $P$. contorta or P. mugo (Ledgard 2009b). This can be challenging if the tree has multiple leaders or has a twisted form. In such situations, standard procedures prescribe a stump-treatment with herbicides because resprouts are harder to cut on the second attempt (Ledgard $2009 \mathrm{~b})$. Top surface mulching is also often unsuccessful. Paul and Ledgard (2009) found a reduction of only $\sim 20 \%$ in the number of invasive pines on a recently mulched control site.

Burning of invasive Pinaceae is often promoted as the cheapest removal technique (Ledgard 2001), but has only been used sporadically to manage pine invasions in New Zealand. Due to the complex effects of terrain, variability of fuel load in an invaded area, and weather, the control success or the complete removal of live pines is often low. Unsuccessful burns can cause a new pine cohort to establish (Hunter and Douglas 1984). Also, regulatory restrictions make the use of controlled burns increasingly difficult, and costs for establishing firebreaks, safety measures and potential risks to adjacent properties increase the total cost and effort involved in using fire as a tool to control invasive Pinaceae.

New Zealand has conducted substantial research on chemical methods for controlling invasive Pinaceae (Gous et al. 2014). Recent advances in the development of herbicide mixtures have made it feasible to eliminate invading Pinaceae, and chemical control is now seen as the most cost-effective method for latestage invasions over large areas (e.g. close stands with canopy closure of 1 ha or more in size). Chemical control is also increasingly used as a cost-efficient option for killing outlier trees or tree clusters at early stages of Pinaceae invasion (Briden et al. 2014; Gous et al. 2015). Overall, herbicide application is costeffective, with approx. NZ\$2000 per ha, compared to mechanical removal, which can cost up to NZ $\$ 10,000$ per ha for stands of tall pines with a closed canopy and high stem density ( $>1000$ stems per hectare), since the highly-trained workers required to do the job are expensive. The high success of herbicide control on invasive Pinaceae is related to the mixture of active ingredients and the application method. Boom spraying using helicopters and spot treatments with a newly developed spray-wand, allow the targeted application of herbicide (Gous et al. 2015). Success rates in boomspray applications with now widely-used chemical mixtures are very high (Gous et al. 2014); minimizing the effort of revisits and additional control. There are, however, concerns about high rates of herbicides applied to control dense invasive pines invasions (particularly P. contorta), and some land-owners still use mechanical methods such as chain-sawing to clear areas even though this method is much more expensive.

Biological control has not been used in New Zealand to control Pinaceae. It has been suggested that Pissodes validirostris, a European pine cone weevil, could be effective for controlling some problematic species, as it affects seed production but not tree growth (larvae develop exclusively in pine cones). The main barrier to the use of biocontrol for Pinaceae are the potential non-target effects. It is feared that the introduction of $P$. validirostris could aid the dispersal of pitch canker, since weevils make wounds on the tree that could favor the spread of the disease (Lennox et al. 2009). However, a recent review from New Zealand found that it is unlikely that $P$. validirostris will aid the spread of pitch canker since there are no insect species in the country that could act as a vector of the canker. It might therefore be safe to use this biocontrol agent as it is unlikely to cause problems for forestry (Brockerhoff et al. 2016).

Recently, it has also been realized that local or regional efforts might not be enough to gain control of pine invasions. While local-scale invasions have been successfully removed, e.g. in parts of the North Island of New Zealand (parts of the Central Plateau) and in parts of the high country in the South Island (Ledgard 2011), nationwide control of pine invasions has not been achieved. Therefore, New Zealand is now adopting a collaborative approach for managing invasive conifers at a national scale through the National Strategy for Wilding Conifer Management (MPI 2014). This strategy was developed with input from all affected parties, including farmers, foresters, and land authorities.

Managing Pinaceae invasions in South Africa In South Africa, management of invasive Pinaceae is 
largely based on mechanical control and the use of fire (Fig. 1). Pinaceae species that invade fynbos ecosystems in the Eastern and Western Cape provinces are killed by fires, but spread over considerable distances via wind-dispersed seeds that germinate in the post-fire environment. Control is achieved by felling trees and burning the vegetation 1-2 years later to kill new seedlings before they produce seeds again (van Wilgen et al. 1992). The Working for Water program (WfW) in South Africa provides an example of how a country with limited resources has attempted to address the control of invasive species. WfW was launched to address social and environmental problems in an integrated manner. Despite its potential, WfW faces many challenges. These include a reluctance to allow untrained labor to use power tools, or to conduct prescribed burning because of safety concerns. It is also difficult to reach invasive populations in remote and rugged terrain (Roura-Pascual et al. 2009; van Wilgen et al. 2012; van Wilgen and Wannenburgh 2016) which means that overall progress with mechanical clearing of pines has been limited. This has led to proposals for a radical overhaul of the strategy for dealing with the growing extent of pine invasions in fynbos ecosystems to refocus the program back on invasion control as the primary goal, rather than the current main goal of job creation (van Wilgen et al. 2016b). At current levels of funding, it is unlikely that pine invasions can be controlled everywhere. Success has been achieved in clearing some landscapes of invasive pines at least in the short term, although preventing re-invasion from neighboring invaded sites or plantations is a major concern (van Rensburg et al. 2017).

Research has been done to determine the feasibility of applying biological control to reduce seed production of invasive pines in South Africa using the seedattacking insect $P$. validirostris, the same species suggested for New Zealand, and it was found to be potentially suitable (Moran et al. 2000). However, the forestry industry has opposed the release of the agent due to concerns that the weevil may act as a vector for the dispersal of pitch canker which affects commercially-important pine species (Lennox et al. 2009). Nevertheless, given the escalating negative consequences of pine tree invasions, the question of whether research on this biological control option should resume remains open for debate (Hoffmann et al. 2011).

Despite the strong legislative framework that exists for invasive species management in general in South Africa, invasive Pinaceae pose particularly daunting challenges given the many species and ecosystems involved and the conflicts of interest that exist (van Wilgen and Richardson 2012). A national strategy for dealing with invasive Pinaceae, along the lines of those proposed for invasive Acacia (van Wilgen et al. 2011) and Prosopis species (Shackleton et al. 2017) is urgently needed.

Lessons learned from South Africa and New Zealand show that, with significant effort, effective control of invasive Pinaceae can be achieved. They

\section{Box 1}

WHO PAYS? COST/BENEFIT ANALYSES OF WHEN AND HOW TO INTERVENE

Costs and benefits of controlling Pinaceae invasions can vary substantially depending on when, how, and where the control is applied. The figure conceptualizes the costs of different control measurements at different stages of the introduction-naturalizationinvasion continuum. For example, banning the use of certain Pinaceae species will result in lost opportunities for the forestry industry. If no ban is applied, no immediate negative effect of the invasion is seen and no immediate cost is incurred (but impacts of the invasion can take decades to manifest). The benefit of a ban would be realized years or decades after implementation of the action: economic and ecological benefits could be substantial while the cost would be relatively low (the loss of an uncertain opportunity). At the other extreme, if the invasion is widespread at the regional level, eradication is impossible but reducing the extent of the invasion and severity of impacts is possible. The cost of control would be in the hands of the forestry industry, private land owners see their land invaded, and typically the local government that need to allocate funds to manage the invasion in its own areas where impacts on local citizens are evident or possible (such as keeping the road shoulders free from pine trees) or are seen as important for other environmental benefits to society or the economy (e.g. natural heritage or water supply). If appropriate management measurements are not taken, many actors are affected-from the public whose activities are disrupted by the invasion (e.g. change in the perceived value of landscapes, reduced access to certain sites) to the forestry industry which faces non-certification, leading to loss in market share as an economic result, and other land users that cannot use the invaded areas for their preferred activities. Our hypothetical analysis shows that as the number of actors affected by the Pinaceae invasion increases, the cost and complexity of controlling such invasions increases (Fig. 2) 


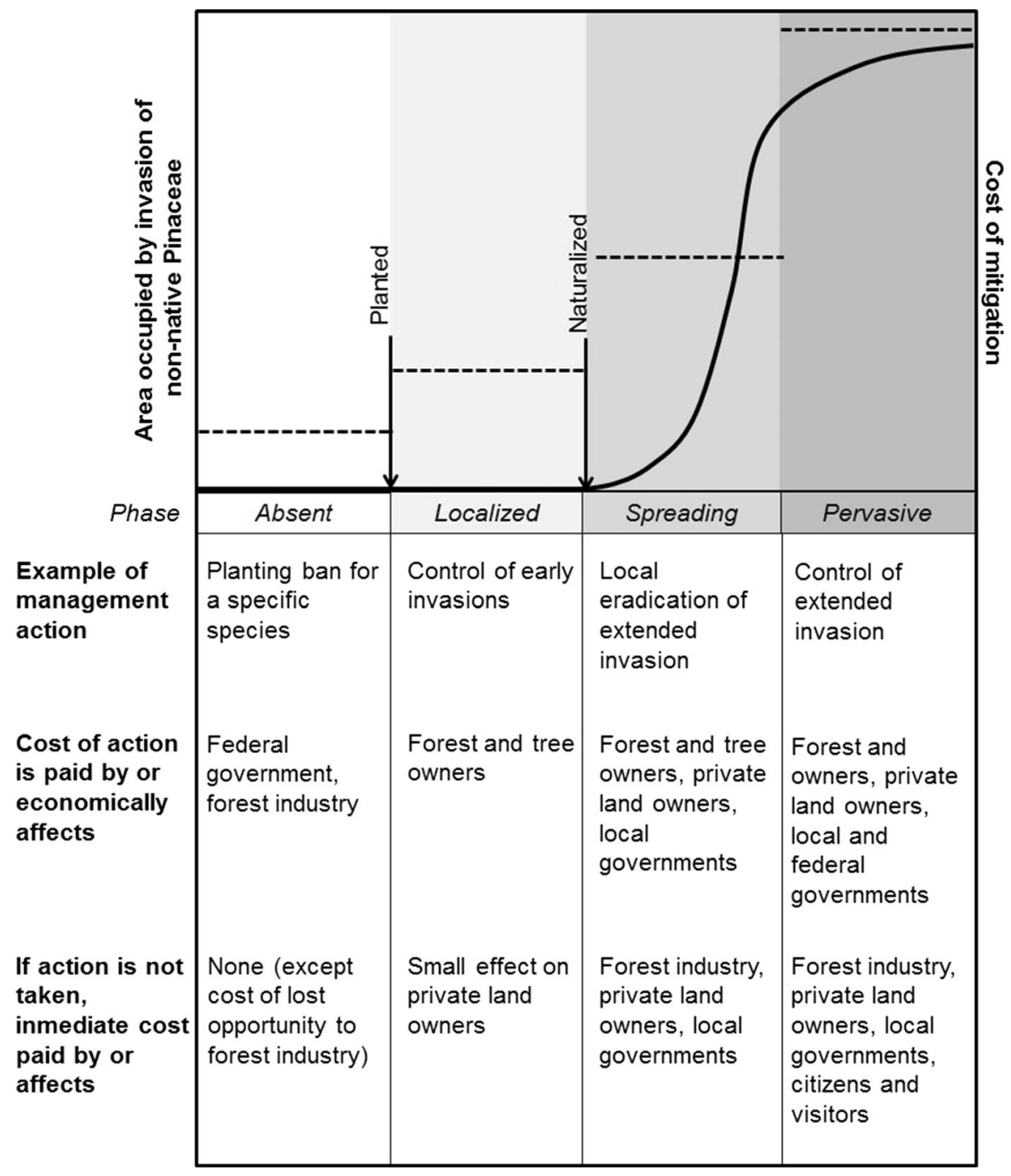

Fig. 2 Cost bearers and parts affected by the decision to control or not control invasive pines (see Box 1). The solid curve represents the pattern of spread of a non-native invasive Pinaceae. Dashed lines show the hypothetical cost of mitigation at different stages of the introduction-naturalization-invasion continuum. Vertical arrows delineate two steps of the process

also show that different approaches, if systematically implemented, can be effective. It has been suggested that different countries or regions may need different solutions (Nuñez and Pauchard 2010; Pauchard et al. 2010). Although there is no evidence from anywhere of success of controlling Pinaceae invasions over large geographical areas (e.g. at country or even regional level), the tools required to control invasions exist and have been implemented successfully over smaller spatial scales (e.g. landscape level). The fundamental before the spreading phase. Examples of management actions and costs are given. Both spread and costs curves are hypothetical and assume a limited area to be occupied by the invasion, many other curves could also be possible. Modified from Lovett et al. (2016)

challenge is to up-scale such efforts over much larger areas. Experience shows that such scaling up is extremely complex (Box 1).

\section{Case studies of management of invasive Pinaceae}

Argentina Pinaceae invasions currently occur in different parts of the country, from deserts or grasslands to forests and rainforests (Simberloff et al. 2002; Sarasola et al. 2006; Zalba et al. 2008; 
Giorgis and Tecco 2014). There are invasions in all areas where Pinaceae species are planted for forestry, and there are very limited efforts to control invasion, mostly using mechanical methods. Most control efforts are applied by the National Parks Administration and some private land owners. A recent notable step towards the prevention of Pinaceae invasions has been a ban on subsidies for plantations of $P$. contorta, a highly invasive species, which was previously heavily subsidized by the national government. A handbook of good plantation practices was recently published and should have a strong influence on agencies that grant subsidies and on foresters. This handbook includes a chapter on the problems of invasions and how to prevent and manage tree invasions (Chauchard et al. 2015). Future challenges include the control of existing invasions, which is currently receiving almost no attention in most parts of the country, and the acceptance by foresters of practices that reduce the spread of Pinaceae species. Although invasion is localized, trends suggest that widespread region-scale invasions will exist in some areas, such as Patagonia, in the next few decades.

Chile Pinaceae plantations cover large areas in southern and central Chile, where they occur in mediterranean-climate, temperate, alpine, and Patagonian ecosystems. At a national scale, Pinaceae invasions currently cover relatively small areas in contrast with the high propagule pressure created by the very large plantation area, especially in central Chile. The total area invaded by Pinaceae is unknown because no national assessment has been conducted. However, Pinaceae invasions occur in ecosystems that are critical for biodiversity conservation, including protected areas (Peña and Pauchard 2001; Gómez et al. 2011; Urrutia et al. 2013). Despite this, neither the government nor the forestry industry has initiated meaningful efforts to control Pinaceae invasions. Control operations currently carried out by forestry companies is limited to extracting Pinaceae species, both planted and invading trees, from riparian areas under protection. Such efforts were initiated due to forest certification agreements that stipulate that forest companies must maintain areas of high conservation value free of invasive species, and restore native vegetation. In protected areas, the Laboratory of Biological Invasions (LIB), in collaboration with
CONAF (National Forest Service of Chile), is exploring techniques for removing Pinaceae, especially Pinus contorta, to minimize damage to the native flora. Assessments are also being done of the impacts and the legacies of such invasions, and of options for promoting the restoration of invaded areas. A major problem for the management of Pinaceae invasions in Chile is that many stakeholders do not distinguish between plantations and invasions. For example, some environmental groups want all Pinaceae stands, whether in plantations or invasive populations in natural vegetation, to be removed from the landscape. This means that any attempt to control invasive Pinaceae is seen by the forestry industry as part of a broader offensive on forest plantations and not as a necessary environmental requirement for their plantings. Thus, for effective control, it is important for stakeholders (forestry companies, government agencies and the public) to separate the impacts of invasions from those generated by plantations. Control efforts should be prioritized to remove Pinaceae invasions from all protected areas and other areas of high conservation value; this is already a requirement for forestry companies under forest certification schemes such as the Forest Stewardship Council (FSC). In addition, those species posing the highest invasion risk (e.g. P. contorta) should be banned from use in plantations, while others should be restricted under specific protocols (e.g. P. menziesii). Forestry companies should integrate the cost of controlling invasive Pinaceae into their operations to reduce negative externalities. Experience from other countries, such as Argentina, New Zealand, and South Africa, may help to implement more rational policies for both Pinaceae plantations and invasions (Richardson et al. 2008). For stakeholders, it is important to have more reliable estimates of the ecological, social, and economic impacts of Pinaceae invasions to allow for the objective prioritization of prevention and control efforts. Research is also needed on methods for restoring ecosystems affected by Pinaceae invasions.

New Zealand Pinaceae plantations are a conspicuous feature of New Zealand landscapes. Pinus radiata plantation forests cover nearly 1.6 $\mathrm{M}$ ha and are an integral part of the production landscape. While spread from these plantations is currently minimal except in coastal areas, the rapid and significant spread of other 
pine species such as $P$. contorta and $P$. nigra has occurred since the mid-twentieth century and is especially widespread in the high country of North and South Islands. P. contorta is currently the most widespread invasive pine species outside of plantations and is the most difficult species to control. It was previously used in large-scale plantings for erosion control, was widely tested for commercial forestry in the high country, and was planted for shelterbelts and woodlots on farms where other tree species showed poor growth. Such "legacy" plantings currently pose the biggest problems for control as they are often in difficult terrain, and responsibilities for their management have been unclear. However, control operations are currently supported by effective tools such as aerial herbicide application which has enabled managers to effectively reduce propagule pressure and to reduce the extent of the invaded area. Pinus contorta is now an unwanted organism under the Biosecurity Act 1993, which means it cannot be bred, propagated, distributed or sold. Other invasive pine species are P. nigra var. laricio, $P$. mugo, $P$. ponderosa, and $P$. pinaster. Several other pine species also cause local-scale problems and threaten conservation and economic values. Local and regional management plans have been developed and implemented since the early 1990s, often to deal with legacy plantings and their spread, but with insufficient budgets. The development and implementation of a National Strategy to manage invasive pines on a national scale has just started (Anon 2014a). The collaborative and cost sharing approach taken under this strategy aims to assign current and future responsibilities in wilding management and provide governmental support to reduce the current area of pine invasions and stop future spread. The area currently invaded is estimated to be approximately $1.7-1.8 \mathrm{M}$ ha, which includes areas of very low invasive pines density (less than one tree per hectare). Challenges for pine invasion management, besides the social acceptance of large-scale control of trees, include:

1. the costly removal of old plantings which act as major seed sources;

2. the increase in management effort in susceptible vegetation types such as semi-natural grasslands because of large-scale abandonment of previously grazed high country farmland; and
3. the increasing evidence of spread of Douglas-fir (P. menziesii; the second most widely planted tree species in New Zealand) from high-country plantations.

South Africa There are very widespread invasions in natural areas adjoining plantations, mainly in the fynbos and grassland biomes of South Africa, where they threaten biodiversity and water resources. Dense stands of self-sown pines cover hundreds of thousands of hectares of protected watersheds in the fynbos biome. Mechanical control, combined with the use of fire, has been used to manage Pinaceae invasions over large areas since the 1970s. There has been good progress in some areas, but recent analyses show that despite a huge investment of resources, the scale of the problem is growing, not shrinking (van Wilgen et al. 2016a). South Africa has legislation that guides invasive species management, but this is difficult to enforce due the scale of the problem and because of unresolved conflicts of interest and a lack of ownership of the problem of invasions in many areas. Despite decades of engagement with the forestry industry in South Africa, conflicts of interest still impede the implementation of effective control (van Wilgen and Richardson 2012). The fact that pines are simultaneously useful and invasive complicates the task of finding sustainable and equitable solutions that would be widely acceptable to all parties. For example, certification of Pinaceae plantations by the Forest Stewardship Council (FSC) requires adherence to sound environmental management practices that follow clear principles, taking account of national laws in the country concerned. Principle 10 of the FSC's criteria for responsible forest management specifies that an applicant for certification "shall only use nonnative species when knowledge and/or experience have shown that any invasive impacts can be controlled and effective mitigation measures are in place". Despite this clear requirement, certification has been granted to South African plantations on the basis that national legislation deals with the responsibility of certified foresters to control spread, even though this legal obligation is clearly not met. Future challenges include the urgent need to improve the efficiency of control measures over large areas, and finding common ground with the forestry industry to agree on protocols to deal with current Pinaceae 
invasions and prevent new invasions. New approaches for assisting private landowners to tackle pine invasions are urgently needed (van Rensburg et al. 2017).

United States The broad diversity and area extent of native Pinaceae species in the United States has discouraged the introduction of non-native species. Those species that were introduced were planted over small areas and there are few records of invasions. Examples of introduced species among other European conifers are Pinus halepensis, P. mugo, P. nigra, $P$. pinaster, $P$. sylvestris and $P$. thunbergii. Most nonnative Pinaceae that were planted have not survived, and those that did are not spreading widely. The presence of many natural enemies (dwarf mistletoes, nematodes, fungi, etc.) and the small size of founder populations probably explain the fate of these introductions (Mortenson and Mack 2006). Interestingly, range expansions and encroachment of native Pinaceae species are well-known phenomena in many parts of the USA, especially after disturbances such as fire or grazing (Richardson and Bond 1991; Simberloff et al. 2012). Such range expansions of native Pinaceae species have resulted in the conversion of grasslands to woodlands or forests, where graminoids and herbs have been replaced by shade-tolerant herbs. The impact of these invasions by native Pinaceae is such that substantial management efforts have been undertaken with the aim of restoring native ecosystems. Tree removal has resulted in a rapid change in species abundance and composition towards the original communities (Halpern et al. 2012). On the other hand, applying fire showed no evidence of restoration effect as a management strategy, even though fire is considered critical for maintaining grasslands (Halpern et al. 2012; Kremer et al. 2014). Burning following tree removal depressed native species richness and different native life forms were favored after such treatment, especially those adapted to disturbance (Halpern et al. 2014). Such management experiences suggest that encroachment of native Pinaceae species has not reach the point where recovery of native ecosystems is complex and costly. In most cases, tree removal alone can promote ecosystem recovery, the main concern being seed rain and reinvasion (Halpern et al. 2012, 2014; Kremer et al. 2014).

Europe Since many European countries have the same pattern regarding Pinaceae invasions, their situation has been described together. Many nonnative Pinaceae species have been introduced to Europe and many have become naturalized. Pseudotsuga menziesii is the species that has become naturalized in most countries, and the United Kingdom is the country with the most naturalized Pinaceae species (Richardson and Rejmánek 2004). Other species introduced to Europe are Pinus banksiana, $P$. ponderosa, $P$. radiata, $P$. rigida, $P$. strobus and $P$. wallichiana (Carrillo-Gavilán and Vilà 2010; Essl et al. 2011). There are occasional records of invasions of non-native Pinaceae species (Engelmark et al. 2001), but this is not a major concern as evidenced by the low number of scientific articles on the subject (Carrillo-Gavilán and Vilà 2010). The limited expansion of non-native Pinaceae species in Europe is probably due to the low introduction effort (and therefore propagule pressure) and phylogenetic closeness between non-native and native species. The only introduced species that have been planted at large scales are P. menziesii and Pinus strobus (Krumm and Vítková 2016), but even for these species records of invasions are not abundant (Essl et al. 2011). There is no evidence of large-scale management efforts in Europe, which suggests that rather minor importance is attached to non-native Pinaceae invasions. However, close monitoring should be carried out to identify invasive populations and control them at an early stage (Carrillo-Gavilán and Vilà 2010).

Restoring invaded areas: What happens after Pinaceae are removed?

The aim of controlling invasive species is usually to achieve effective removal, recover the structure and composition of the preexisting communities and to prevent re-invasion in treated areas (Paul and Ledgard 2009; MPI 2014). However, after Pinaceae stands are removed, restoration to preexisting states can be a challenge (Dickie et al. 2014b; Wardle and Peltzer 2017). An understanding of the impacts and consequences of the applied control method (Paul and Ledgard 2009) and also alternative management techniques, will contribute towards improving ecological restoration (Holmes et al. 2000). In certain situations, the removal of the invasive Pinaceae species might be sufficient for restoring the structure and composition of native communities (e.g. seeds of 
suitable native species readily available), but in others re-invasion of pines or other alien plants causes problems (Dickie et al. 2014b). In other cases, the control of invasive species must be combined with ecological restoration efforts such as seed and plant enrichment or stimulation of native species seed bank (Warren et al. 2002; McAlpine et al. 2016). If such restoration efforts are not carried out, invasive Pinaceae species removal could lead to the establishment of other non-native species (i.e. secondary invasions) (Dickie et al. 2014b; Kuebbing and Nuñez 2015; Pearson et al. 2016; Mostert et al. 2017). A major task for managers is to identify the situation in particular ecosystems and to adjust plans accordingly (Gaertner et al. 2012).

\section{How different control techniques affect succession and restoration}

Although the success of invasive species control often relies on the effectiveness of removal of the target species and the prevention of its re-invasion, the impact of the management technique also needs to be considered with reference to restoration goals (Paul and Ledgard 2009). Different control techniques differ in their ecological consequences (e.g. effect on diversity of different guilds or probabilities of restoration), and even the same technique can have different effects on vegetation succession, depending on site conditions and level of invasion (e.g. Dickie et al. 2014b).

Clearcutting is a commonly used technique for controlling invasive Pinaceae. Once a tree has been felled, it can be removed or left on site as "slash" (i.e. felling to waste) (Paul and Ledgard 2008). Felling and removal result in the disturbance of topsoil and the understory, while felling to waste results in slash remaining on site that protects the undisturbed topsoil but often shades out any existing understory vegetation. In contrast, the removal of Pinaceae trees causes a sudden change in the insolation and water dynamics of the soil (Cuevas and Zalba 2010) that could lead to stressful environments for native tree seedlings (Hourdequin 1999). Both tree removal and felling to waste may change vegetation succession relative to natural areas, as native or non-native pioneer species are often promoted by the increased resource availability (light and nutrients) (Brockerhoff et al. 2003; Cuevas and Zalba 2010; Dickie et al. 2014b). However, there may also be positive changes associated with felled trees left on site. For instance, the slash benefits shadetolerant species and provides perch sites for birds that disperse native species (Paul and Ledgard 2009). Herbicide application or ringing techniques leave the Pinaceae tree standing dead which leads to gradual changes in canopy cover as trees lose their needles and branches. Along with changes in the light environment, belowground competition may be reduced (McAlpine et al. 2016) and dead standing trees may act as 'nurses', facilitating native species establishment (Paul and Ledgard 2009; McAlpine et al. 2016). Evidence from New Zealand suggests that herbicide application is the best technique for promoting native vegetation succession (McAlpine et al. 2016).

Burning as a management tool in South Africa has generated different outcomes depending on the density of pines, whether they are felled before burning or not, and whether the resultant fuel is removed prior to burning or not. The 'fell and burn' treatment was found to have the greatest negative effect on vegetation recovery (Holmes et al. 2000), as it often results in exceptionally intense fires (van Wilgen et al. 1992). Because of practical problems associated with the 'burn standing' and 'fell, remove and burn' treatments, managers often have little choice but to apply the 'fell and burn' treatment. There are dangers in this approach which highlights the need for intervention before areas become densely invaded. Where weed species are more abundant, techniques that generate minimal disturbance instead of burning should be implemented (i.e. manual removal or stem injection) (Kasel and Meers 2004). Regardless of the capacity of the seed bank to germinate after fire, if Pinaceae invasions increase fuel loads, increased fire intensity could cause poor regeneration from native seed banks and favor non-native species recruitment (van Wilgen 2012; Taylor et al. 2017).

\section{Legacy effects}

Some impacts of Pinaceae invasion persist after removal of invasive stands (i.e. legacy effects), regardless of removal technique (Cuddington 2011), and these may alter vegetation succession (Wardle and Peltzer 2017). For instance, Dickie et al. (2014b) found that the removal of stands of mature pine trees may not lead to the restoration of semi-natural tussock grasslands and shrubland vegetation that existed prior 
to Pinus invasion. Tree invasion increased nutrient cycling rates with the concomitant increase in nutrient availability ( $\mathrm{N}$ and $\mathrm{P}$ ) and favored ectomycorrhizal invasion (Dickie et al. 2011, 2014b). These changes persisted in soils after tree removal and not only hindered native regeneration, but also facilitated invasion of other pine trees, although the effect of their removal depended on invasion duration (Dickie et al. 2014b). Also, in early stages of pine invasions, the felling of individual trees resulted in higher native grass coverage on the site of the decaying tree in the medium term $(<10$ years) (Paul and Ledgard 2008).

In Chile, preliminary results suggest that litter is one of the main physical legacies of pine invasions (A. Pauchard, unpublished results). Because of its chemical composition, pine litter takes longer to degrade than native tree litter (Araujo and Austin 2015). However, by opening the canopy, there may be an increase in litter decomposition rates due to higher radiation and higher temperatures. The legacy effect will not only be driven by the species but also by the biotic and abiotic characteristics of the invaded ecosystem, and the invasion stage of the controlled Pinaceae stand. Older invasive Pinaceae stands have lost most of their native plant and animal diversity, and therefore it may take much longer to achieve restoration goals.

In South African fynbos, the legacy effects in areas cleared of invasive or planted pines are generally much less pronounced than those observed in cleared stands of Australian Acacia species (Mostert et al. 2017).

\section{Ways to maximize restoration efforts}

Efforts to control invasive Pinaceae do not always lead to the restoration of native vegetation, particularly if the restoration goal was to achieve non-woody indigenous low-stature vegetation. Furthermore, there may have to be a trade-off between the most costeffective technique of removing the invasive trees, and the best options for ensuring recovery of native vegetation (e.g. Holmes et al. 2000). However, the 'no action' alternative (i.e. no invasive control) increases invader seed supply and potential spread to novel sites (Kettenring and Adams 2011).

Although there is no fixed set of procedures for ecological restoration (Moore et al. 1999), several key factors need to be considered before and during invasion control. Restoration effectiveness depends mainly on the capacity of native species to recolonize the site, which in turn depends on recruitment from the soil seed bank, growth of persistent species that have survived under pine canopy and/or have established from seed from the surrounding vegetation, and appropriate soil conditions (Holmes and Richardson 1999; Cuevas and Zalba 2010; Wardle and Peltzer 2017). The composition and abundance of the vegetation in the plantation/invasion understory could be a useful predictor of the likelihood of the early restoration after clearcutting (Yamagawa et al. 2010). As some native understory species persist under plantations of Pinaceae species (Richardson and van Wilgen 1986; Brockerhoff et al. 2003) and in invaded sites (Howell and McAlpine 2016), recovery of native vegetation can be enhanced by certain management actions (Paul and Ledgard 2009; McAlpine et al. 2016). For instance, understories dominated by shadetolerant species can be enhanced by gradual changes in light environment by partial cuttings or thinning, and avoiding clearcuts (Brockerhoff et al. 2003; Yamagawa et al. 2010) or by poisoning standing trees (Ledgard 2009a). Furthermore, as some invasive conifer trees may facilitate native species establishment, restoration process should first assess the potential use of non-native plants for restoration actions before eradication of the pines (Becerra and Montenegro 2013). Also, although interventions to reduce soil legacy effects by reconstructing previous assemblages of soil biota (e.g. mycorrhizal fungi) have rarely been attempted, such actions may be crucial for achieving success, especially in heavily modified environments (Wardle and Peltzer 2017).

The seed bank and seed rain are important sources for the regeneration of natural vegetation in invaded sites (Holmes and Richardson 1999; Moles and Drake 1999). Where the seed bank is dominated by nonnative species, native succession after invasive control is unlikely, and further restoration efforts, such as enrichment or stimulation of the native seed bank, may be necessary (McAlpine et al. 2016). The remnants of native vegetation can act as sources of seed rain, and thus the relative position of the invaded area in the landscape is a key factor determining restoration success (Holmes and Richardson 1999; Cuevas and Zalba 2010; Yamagawa et al. 2010). Therefore, seed sowing may be also necessary where landscapes are highly fragmented and options for seed transport between fragments are limited (Buckley et al. 2005). 
The timing of management intervention also matters. With the development of dense and large invasions we can expect a negative correlation with the availability of native propagules due to the increasing exclusion of native species in an invaded area. For example, Cuevas and Zalba (2010) showed that longer invasion times lead to less successful restoration due to the eroded seed bank of native species on such sites. If native succession is based on improving understory vegetation, it may also depend on stand age because non-native species become less frequent as the canopy closes and available light decreases (Brockerhoff et al. 2003). Furthermore, the time of the year when the control is carried out can determine the availability of native propagules in terms of flowering time of native species (Cuevas and Zalba 2010). On the other hand, legacy effects that hinder native regeneration appear to be more common in mature stands (i.e. long time elapsed since invasion). The longer the duration of invasion, the greater the probability of occurrence of a novel stable state and the need for substantially greater inputs for restoration (Gaertner et al. 2012; Dickie et al. 2014b).

Another common challenge for restoration is the ongoing seed pressure from the initial source of invasion, remnant uncontrolled Pinaceae trees, or recruitment from the seed bank (e.g. viable seeds in cones on dead trees). The result can be a complicated scenario where controlled areas can be reinvaded at higher densities than the initial invasion. In this context, one way to maximize restoration efforts is to prioritize management in invaded areas with higher spread risk (Buckley et al. 2005; Mason et al. 2017). Seed-producing pines upwind of vulnerable habitat (i.e. more exposed to dispersion by wind) and pines with a high volume of dispersible propagules (i.e. mature stands) should be prioritized for control (Buckley et al. 2005). Frequent monitoring of a site under restoration can help to identify problematic situations quickly by, for example, helping to identify seed sources that need to be controlled to avoid the reinvasion of a site.

\section{The way forward}

The experience with Pinaceae introduction, naturalization and invasion around the world has created a valuable natural experiment that helps to understand the roles of different biotic and abiotic factors that determine which species become invasive and how invasions proceed. Similarly, experiences from around the world on ways of managing invasive Pinaceae are useful for generating knowledge on which we can build more successful strategies.

Every situation or invasion scenario is unique (including different species, histories of planting, residence time, socio-political situations, availability of resources for management, and legislation), but some general principles are emerging. Early detection and rapid response, as with many other invasive species, is key, since well established (i.e. widespread and dense) invasions are harder to control. Early detection through well designed surveillance is especially useful for Pinaceae, as it can allow an effective response due to the relative slow invasion rates of these trees (e.g. several years to reach maturity) compared to other invasive species where extremely fast response is critical (Hulme 2006). This is especially crucial in areas where plantations or source populations of invasive Pinaceae are found. Largescale eradication is not a viable option for most invasive Pinaceae, since the source of propagules may need to persist for economic reasons, as in the case of invasions that originate from plantations. Even if seeding cannot be eradicated, an acceptable level of control of the resulting invasions can be achieved through diligence and ongoing management efforts which add a cost over the life of the plantation.

A range of techniques hold promise for controlling Pinaceae invasions. Mechanical and methods and the use of fire are most commonly applied globally. Biological control might also be effective in some areas but has yet to be applied. The ideal technique for a given situation will depend on the cost and availability of labor and other resources, the stage of the invasion, and the acceptance of the use of a particular method in a given region (e.g. herbicides or biological control). As with all invasions, there is a need for a suite of measures to address different issues along the introduction-naturalization-invasion continuum. There is currently much interest in applying genetic techniques in invasive species management (Ricciardi et al. 2017). Genetic engineering to achieve reproductive sterility could potentially reduce invasiveness in many tree taxa, including Pinaceae. However, such solutions pose many challenges. For example, criteria for forest certification current 
prohibit the use of any genetically-modified planting, thus blocking a potentially useful avenue of intervention (Richardson and Petit 2005). This is clearly an issue that requires further deliberation.

Although currently Pinaceae invasions are creating large ecological and economic problems, with millions of hectares invaded and invasions increasing rapidly in many countries, many different tools are available to control them. Mason et al. (2017) propose a way of prioritizing control efforts by minimizing negative impacts and maximizing positive impacts on multiple ecosystems. They propose using spatial models to map the negative impacts of invasive conifers on biodiversity, perceived landscape quality, and water yield and their positive impacts on erosion protection and carbon storage across a major catchment in the South Island of New Zealand. This approach could help to reduce costs and minimize social conflicts, thereby guiding efforts to concentrate funding for more effective control.

Despite the technical possibilities of controlling Pinaceae invasions, there are many challenges regarding their control. Different areas face different difficulties but some of the most important challenges are the large spatial scale of the problem, the lack of political determination, the limited economical resources, and the lack of proper environmental awareness and regulations. Solving these problems is a fundamental step that will be key to achieve the goal of controlling Pinaceae invasions.

Forestry operations have been and remain the principal driver of current Pinaceae invasions globally, and enhanced cooperation with forestry companies is fundamental for achieving more effective strategies to reduce problems with these invasions. Engagement with forestry companies and other stakeholders is crucial for ensuring appropriate framing the dimensions of the invasions within local, regional, national, and international contexts (Woodford et al. 2016). To this end, the Bern Convention (Convention on the Conservation of European Wildlife and Natural Habitats) commissioned a Code of Conduct on Planted Forest and Invasive Alien Trees to guide sustainable forestry practices in Europe to deal with invasive forestry trees (Brundu and Richardson 2016). The Code is voluntary and is not intended to replace any statutory requirements under international or national legislation in the countries of Europe. It comprises 14 principles that are clustered in five broad groups: (1) awareness; (2) prevention and containment; (3) early detection and rapid response; (4) outreach; (5) forward planning. Different mixtures of interventions are likely to be most appropriate in different regions, given particular national, sociopolitical, legislative, and other contexts. This Code could serve as the foundation for a global strategy for planted forests to mitigate the risks related to the use of invasive non-native trees in forestry.

Stakeholders must work together to seek the best options for reducing Pinaceae invasions and mitigating their impacts. This paper has reviewed advances on several fronts in different parts of the world, including using technological and legislative innovations, to alleviate certain problems associated with Pinaceae invasions. This is an excellent example where a "global network for invasion science" (Packer et al. 2017) is needed to forge local solutions that draw on outcomes of successes and failures around the world in dealing with Pinaceae invasions (see Wilson et al. 2011 for a similar approach for Australian Acacia species).

\section{Conclusions}

Eliminating individual Pinaceae trees from a site is relatively straightforward, but the huge spatial scale of the problem means that dealing with these invasions is a daunting challenge. Millions of hectares are currently invaded and fast responses are needed. Although there are ways to control invasions, the lack of political determination, limited resources and/or proper environmental awareness and regulations have created a rapidly growing problem, as with many other invasive species. Prevention is a critical intervention to avoid future potential impacts of Pinaceae invasions, and research is underway to help minimize the risks of invasion. Reducing the use of highly invasive Pinaceae species in plantings and forestry and using a landscape-wide planning approach are central to diminishing current and future invasions. In the case of existing invasions, mechanical and chemical control have proved very efficient, but their costs can be problematic in large areas. A future challenge is to restore areas invaded by Pinaceae species to preferred and possibly more resilient ecosystems (e.g. native forests and shrublands). Restoration of previously invaded sites is achievable in some cases, but in many 
cleared sites restoration is difficult. Once invasions have reached very high density and biomass, the chances of restoring systems to previous conditions are greatly reduced. This review of the current understanding of Pinaceae invasions highlights the need for more attention on preventing further invasions and initiating control at the earliest stages of invasions.

Acknowledgements We thank M. Gundale, A. Carrillo Gavilán, K. Taylor and L Vítková for providing information on Pinaceae management from Europe and the USA. AP and RG were funded by Fondecyt Grant 1140485 and the Institute of Ecology and Biodiversity Grants ICM P05-002 and CONICYT PFB-23. DMR and BWvW acknowledge support from the DSTNRF Centre of Excellence for Invasion Biology and the Working for Water Programme through their collaborative research project on "Integrated Management of invasive alien species in South Africa", and the National Research Foundation (Grant 85417 to DMR; Grant 87550 to BWvW). MN and JM were funded by PICT 2014-0662 of the ANPCyT of Argentina. TP acknowledge support from the Sustainable Farming Fund (Ministry for Primary Industries; No. 13/031).

\section{References}

Adamowski W (2004) Why don't alien conifers invade the Bialowieza Forest? Weed Technol 18:1453-1456

Anon (2014a) New Zealand wilding conifer management strategy. A non-regulatory strategy for the management of wilding conifers in New Zealand. Ministry of Primary Industry of New Zealand, $40 \mathrm{pp}$

Anon (2014b) National exotic forest description. Ministry of Primary Industries, Wellington

Araujo PI, Austin AT (2015) A shady business: pine afforestation alters the primary controls on litter decomposition along a precipitation gradient in Patagonia, Argentina. J Ecol 103:1408-1420

Ashkannejhad S, Horton TR (2006) Ectomycorrhizal ecology under primary succession on coastal sand dunes: interactions involving Pinus contorta, suilloid fungi and deer. New Phytol 169:345-354

Becerra PI, Bustamante RO (2008) The effect of herbivory on seedling survival of the invasive exotic species Pinus radiata and Eucalyptus globulus in a Mediterranean ecosystem of Central Chile. For Ecol Manag 256:1573-1578

Becerra PI, Montenegro G (2013) The widely invasive tree Pinus radiata facilitates regeneration of native woody species in a semi-arid ecosystem. Appl Veg Sci 16:173-183

Benecke U (1967) The weed potential of lodgepole pine. Tussock Grassl Mt Lands Inst Rev 13:36-42

Bohrer G, Katul GG, Nathan R, Walko RL, Avissar R (2008) Effects of canopy heterogeneity, seed abscission and inertia on wind-driven dispersal kernels of tree seeds. J Ecol 96:569-580

Briden K, Raal P, Gous S (2014) Improving methods for wilding conifer control in New Zealand. In: Proceedings of nineteenth Australian weeds conference, Hobart, Tasmania, Australia, pp 369-371. http://caws.org.au/awc/2014/ awc201413691.pdf. Accessed Sept 2016

Brockerhoff EG, Ecroyd CE, Leckie AC, Kimberley MO (2003) Diversity and succession of adventive and indigenous vascular understorey plants in Pinus radiata plantation forests in New Zealand. For Ecol Manag 185:307-326

Brockerhoff EG, Dick M, Ganley R, Roques A, Storer AJ (2016) Role of insect vectors in epidemiology and invasion risk of Fusarium circinatum, and risk assessment of biological control of invasive Pinus contorta. Biol Invasions 18:1177-1190

Brundu G, Richardson DM (2016) Planted forests and invasive alien trees in Europe: a code for managing existing and future plantings to mitigate the risk of negative impacts from invasions. NeoBiota 30:5-47

Buckley YM, Brockerhoff E, Langer L, Ledgard N, North H, Rees M (2005) Slowing down a pine invasion despite uncertainty in demography and dispersal. J Appl Ecol 42:1020-1030

Buckley YM, Anderson S, Catterall CP, Corlett RT, Engel T, Gosper CR, Nathan R, Richardson DM, Setter M, Spiegel O, Vivian-Smith G, Voigt FA, Weir JES, Westcott DA (2006) Management of plant invasions mediated by frugivore interactions. J Appl Ecol 43:848-857

Burns RM, Honkala BH (1990) Silvics of North America. Agriculture handbook 654, vol 1. United States Department of Agriculture, Forest Service, Washington

Caccia FD, Ballaré CL (1998) Effects of tree cover, understory vegetation, and litter on regeneration of Douglas-fir (Pseudotsuga menziesii) in southwestern Argentina. Can J For Res 28:683-692

Carrillo-Gavilán MA, Vilà M (2010) Little evidence of invasion by alien conifers in Europe. Divers Distrib 16:203-213

Chauchard L, Frugoni MC, Nowak C (2015) Buenas prácticas para el manejo de plantaciones forestales en el noroeste de la Patagonia. Ministerio de Agroindustria Argentina

Crous CJ, Burgess TI, Le Roux JJ, Richardson DM, Slippers B, Wingfield MJ (2016) Ecological disequilibrium driving insect pest and pathogen accumulation in non-native trees in South Africa. AoB Plants 9:plw081. doi:10.1093/aobpla/ plw081

Cuddington K (2011) Legacy effects: the persistent impact of ecological interactions. Biol Theory 6:203-210

Cuevas YA, Zalba SM (2010) Recovery of native grasslands after removing invasive pines. Restor Ecol 18:711-719

Davis M, Grace L, Horrell R (1996) Conifer establishment in the South Island high country: influence of mycorrhizal inoculation, competition removal, fertilizer application, and animal exclusion during seedling establishment. N Z J For Sci 26:380-394

Dehlin H, Peltzer DA, Allison VJ, Yeates GW, Nilsson MC, Wardle DA (2008) Tree seedling performance and belowground properties in stands of invasive and native tree species. N Z J Ecol 32:67-79

Dickie IA, Reich PB (2005) Ectomycorrhizal fungal communities at forest edges. J Ecol 93:244-255

Dickie IA, Bolstridge N, Cooper JA, Peltzer DA (2010) Coinvasion by Pinus and its mycorrhizal fungi. New Phytol 187:475-484

Dickie IA, Yeates GW et al (2011) Ecosystem service and biodiversity trade-offs in two woody successions. J Appl Ecol 48:926-934 
Dickie IA, Bennett BM, Burrows LE, Nunez MA, Peltzer DA, Porté A, Richardson DM, Rejmánek M, Rundel PW, van Wilgen BW (2014a) Conflicting values: ecosystem services and invasive tree management. Biol Invasions 16:705-719

Dickie IA, St John MG, Yeates GW, Morse CW, Bonner KI, Orwin K, Peltzer DA (2014b) Belowground legacies of Pinus contorta invasion and removal result in multiple mechanisms of invasional meltdown. AoB Plants 6:plu056

Dickie IA, Nuñez MA, Pringle A, Lebel T, Tourtellot SG, Johnston PR (2016) Towards management of invasive ectomycorrhizal fungi. Biol Invasions 18:3383-3395

Engelmark O, Sjöberg K, Andersson B, Rosvall O, Ågren GI, Baker WL et al (2001) Ecological effects and management aspects of an exotic tree species: the case of lodgepole pine in Sweden. For Ecol Manag 141:3-13

Essl F, Moser D, Dullinger S, Mang T, Hulme P (2010) Selection for commercial forestry determines global patterns of alien conifer invasions. Biodivers Res 16:911-921

Essl F, Mang T, Dullinger S, Moser D, Hulme PE (2011) Macroecological drivers of alien conifer naturalizations worldwide. Ecography 34:1076-1084

Gaertner M, Holmes PM, Richardson DM (2012) Biological invasions, resilience and restoration. In: van Andel J, Aronson J (eds) Restoration ecology-the new frontier. Wiley-Blackwell, Oxford, pp 265-280

García RA, Engler ML, Pollnac F, Pauchard A (2015) Fuel characteristics of the invasive Teline monspessulana (L.) K. Koch. Int J Wildland Fire 24:372-379

Giorgis MA, Tecco PA (2014) Árboles y arbustos invasores de la Provincia de Córdoba (Argentina): una contribución a la sistematización de bases de datos globales. Bol Soc Argent Bot 49:581-603

Gómez P, Bustamente R, San Martín J, Hahn S (2011) Estructura poblacional de Pinus radiata $\mathrm{D}$. Don en fragmentos de Bosque Maulion en Chile central. Gayana Botánica 68:97-101

Gous S, Raal P, Watt MS (2014) Dense wilding conifer control with aerially applied herbicides in New Zealand. N Z J For Sci 44:4

Gous S, Raal P, Kimberley MO, Watt MS (2015) Chemical control of isolated invasive conifers using a novel aerial spot application method. Weed Res 55:380-386

Greenaway A, Bayne K et al (2015) Evaluating (non-market) impacts of wilding conifers on cultural values. Landcare Research Scion, Auckland

Greene DF, Kneeshaw DD, Messier C, Lieffers V, Cormier D, Doucet R et al (2002) Modelling silvicultural alternatives for conifer regeneration in boreal mixedwood stands (aspen/white spruce/balsam fir). For Chron 78:281-295

Grotkopp E, Rejmánek M, Rost TL (2002) Toward a causal explanation of plant invasiveness: seedling growth and life history strategies of 29 pine (Pinus) species. Am Nat 159:396-419

Gundale MJ, Pauchard A, Langdon B, Peltzer DA, Maxwell BD, Nuñez MA (2014) Can model species be used to advance the field of invasion ecology? Biol Invasions 16:591-607

Gundale MJ, Almeida JP, Wallander H, Wardle DA, Kardol P, Nilsson MC, Fajardo A, Pauchard A, Peltzer DA, Ruotsalainen S, Mason B (2016) Differences in endophyte communities of introduced trees depend on the phylogenetic relatedness of the receiving forest. J Ecol 104:1219-1232

Halpern CB, Haugo RD, Antos JA, Kaas SS, Kilanowski AL (2012) Grassland restoration with and without fire: evidence from a tree-removal experiment. Ecol Appl 22: $425-441$

Halpern CB, Antos JA, Beckman LM (2014) Vegetation recovery in slash-pile scars following conifer removal in a grassland-restoration experiment. Restor Ecol 22:731-740

Hayward J, Horton TR, Nuñez MA (2015a) Ectomycorrhizal fungal communities coinvading with Pinaceae host plants in Argentina: gringos bajo el bosque. New Phytol 208: 497-506

Hayward J, Horton TR, Pauchard A, Nuñez MA (2015b) A single ectomycorrhizal fungal species can enable a Pinus invasion. Ecology 96:1438-1444

Hermann RK, Lavender DP (1990) Pseudotsuga menziesii (Mirb.) Franco Douglas-Fir. In: Burns RM, Honkala BH (eds) Silvics of North America. United States Department of Agriculture, Forest Service, Washington, pp 778-806

Higgins SI, Richardson DM (1998) Pine invasions in the southern hemisphere: modeling interactions between organism, environment and disturbance. Plant Ecol 135:79-93

Hoffmann JH, Moran VC, van Wilgen BW (2011) Prospects for the biological control of invasive Pinus species (Pinaceae) in South Africa. Afr Entomol 19:393-401

Holmes PM, Richardson DM (1999) Protocols for restoration based on recruitment dynamics, community structure, and ecosystem function: perspectives from South African fynbos. Restor Ecol 7:215-230

Holmes PM, Richardson DM, van Wilgen BW, Gelderblom C (2000) Recovery of South African fynbos vegetation following alien woody plant clearing and fire: implications for restoration. Austral Ecol 25:631-639

Hourdequin ME (1999) Ecological restoration after removal of exotic conifer plantations in Argentine Patagonia's Nahuel Huapi National Park. Dissertation, University of Montana

Howell CJ, McAlpine KG (2016) Native plant species richness in non-native Pinus contorta forest. N Z J Ecol 40:131-136

Hulme PE (2006) Beyond control: wider implications for the management of biological invasions. J Appl Ecol 4: $835-847$

Hulme PE (2012) Weed risk assessment: a way forward or a waste of time? J Appl Ecol 49:10-19

Hunter GG, Douglas MH (1984) Spread of exotic conifers on South Island Rangelands. N Z J For 29:78-96

Kasel S, Meers T (2004) Restoration of former pine plantation in Australia: revegetation techniques, pine wilding control and the importance of land use history. In: Int'l conference, society for ecological restoration, Victoria, Canada

Kettenring KM, Adams CR (2011) Lessons learned from invasive plant control experiments: a systematic review and meta-analysis. J Appl Ecol 48:970-979

Kremer NJ, Halpern CB, Antos JA (2014) Conifer reinvasion of montane meadows following experimental tree removal and prescribed burning. For Ecol Manag 319:128-137

Krumm F, Vítková L (2016) Introduced tree species to European forests: challenges and opportunities. European Forest Institute, Bonn. ISBN 978-952-5980-31-8

Kuebbing SE, Nuñez MA (2015) Negative, neutral, and positive interactions among nonnative plants: patterns, processes, 
and management implications. Glob Chang Biol 21: 926-934

Kueffer C, Pyšek P, Richardson DM (2013) Integrative invasion science: model systems, multi-site studies, focused metaanalysis and invasion syndromes. New Phytol 200: 615-633

Langdon B, Pauchard A, Aguayo M (2010) Pinus contorta invasion in the Chilean Patagonia: local patterns in a global context. Biol Invasions 12:3961-3971

Le Maitre DC, van Wilgen BW, Gelderblom CM, Bailey C, Chapman RA, Nel JA (2002) Invasive alien trees and water resources in South Africa: case studies of the costs and benefits of management. For Ecol Manag 160:143-159

Ledgard NJ (2001) The spread of lodgepole pine (Pinus contorta, Dougl.) in New Zealand. For Ecol Manag 141:43-57

Ledgard NJ (2002) The spread of Douglas-fir into native forests. N Z J For 47:36-38

Ledgard NJ (2004) Wilding conifers-New Zealand history and research background. In: Managing wilding conifers in New Zealand-present and future. Proceedings of a workshop held in conjunction with the annual general meeting of the NZ Plant Protection Society, Christchurch, pp 1-25

Ledgard NJ (2009a) Wilding control. Guidelines for the control of wilding conifers. Scion, Rotorua. ISBN 0-478-11028-6

Ledgard NJ (2009b) Wilding control guidelines for farmers and land managers. N Z Plant Prot 62:380-386

Ledgard NJ (2011) What is wrong with wildings? N Z Tree Grow 32:13-15

Ledgard NJ, Langer L (1999) Wilding prevention. Guidelines for minimizing the risk of unwanted wilding spread from new plantings of introduced conifers. New Zealand Forest Research Institute Limited, Rotorua

Lennox CL, Hoffmann JH, Coutinho T, Roques A (2009) A threat of exacerbating the spread of pitch canker precludes further consideration of a cone weevil, Pissodes validirostris, for biological control of invasive pines in South Africa. Biol Control 50:179-184

Lotan JE, Perry DA (1983) Ecology and regeneration of lodgepole pine. Handbook no. 606. United States Department of Agriculture, Forest Service, Washington, p 51

Lovett GM, Weiss M et al (2016) Nonnative forest insects and pathogens in the United States: impacts and policy options. Ecol Appl 26:1437-1455

Mason NWH, Palmer DJ, Vetrova V, Brabyn L, Paul T, Willemse P, Peltzer DA (2017) Accentuating the positive while eliminating the negative of alien tree invasions: a multiple ecosystem services approach to prioritising control efforts. Biol Invasions 19:1181-1195. doi:10.1007/s10530-0161307-y

Maxwell BD, Lehnhoff E, Rew LJ (2009) The rationale for monitoring invasive plant populations as a crucial step for management. Invasive Plant Sci Manag 2:1-9

McAlpine KG, Howell CJ, Wotton DM (2016) Effects of tree control method, seed addition, and introduced mammal exclusion on seedling establishment in an invasive Pinus contorta forest. N Z J Ecol 40:302-309

McConnachie MM, van Wilgen BW, Richardson DM et al (2015) Estimating the effect of plantations on pine invasions in protected areas: a case study from South Africa. J Appl Ecol 52:110-118
McConnachie MM, van Wilgen BW, Ferraro PJ et al (2016) Using counterfactuals to evaluate the cost-effectiveness of controlling biological invasions. Ecol Appl 26:475-483

McGregor KF, Watt MS, Hulme PE, Duncan RP (2012) What determines pine naturalization: species traits, climate suitability or forestry use? Divers Distrib 18:1013-1023

Menzel A, Hempel S, Klotz S, Moora M, Pyšek P, Rillig MC, Zobel M, Kühn I (2017) Mycorrhizal status helps explain invasion success of alien plant species. Ecology 98:92-102

Mikola P (1970) Mycorrhizal inoculation in afforestation. Int Rev For Res 3:123-196

Minore D (1979) Comparative autecological characteristics of northwestern tree species: a literature review. General technical report PNW. United States Department of Agriculture, Forest Service, Pacific Northwest Forest and Range Experiment Station, Portland, Oregon

Moles AT, Drake DR (1999) Potential contributions of the seed rain and seed bank to regeneration of native forest under plantation pine in New Zealand. N Z J Bot 37:83-93

Moore MM, Wallace Covington W, Fule PZ (1999) Reference conditions and ecological restoration: a southwestern ponderosa pine perspective. Ecol Appl 9:1266-1277

Moran VC, Hoffmann JH, Donnnelly D, van Wilgen BW, Zimmermann HG (2000) Biological control of alien, invasive pine trees (Pinus species) in South Africa. In: Spencer NR (ed) Proceedings of the X international symposium on biological control of weeds. Montana State University, Bozeman, pp 941-953

Mortenson SG, Mack RN (2006) The fate of alien conifers in long-term plantings in the USA. Divers Distrib 12:456-466

Mostert E, Gaertner M, Holmes PM et al (2017) Impacts of invasive alien trees on threatened lowland vegetation types in the Cape Floristic Region, South Africa. S Afr J Bot 108:209-222

MPI (2014) The right tree in the right place. New Zealand wilding conifer management strategy 2015-2030. Ministry for Primary Industries. ISBN: 978-0-477-10511-8

Nuñez MA, Dickie IA (2014) Invasive belowground mutualists of woody plants. Biol Invasions 16:645-661

Nuñez MA, Medley KA (2011) Pine invasions: climate predicts invasion success; something else predicts failure. Divers Distrib 17:703-713

Nuñez MA, Pauchard A (2010) Biological invasions in developing and developed countries: does one model fit all? Biol Invasions 12:707-714

Nuñez MA, Relva MA, Simberloff D (2008a) Enemy release or invasional meltdown? Deer preference for exotic and native trees on Isla Victoria, Argentina. Austral Ecol 33:317-323

Nuñez MA, Simberloff D, Relva MA (2008b) Seed predation as a barrier to alien conifer invasions. Biol Invasions 10:1389-1398

Nuñez MA, Horton TR, Simberloff D (2009) Lack of belowground mutualisms hinders Pinaceae invasions. Ecology 90:2352-2359

Nuñez MA, Hayward J, Horton TR, Amico GC, Dimarco RD, Barrios-Garcia MN, Simberloff D (2013) Exotic mammals disperse exotic fungi that promote invasion by exotic trees. PLoS ONE 8:e66832 
Packer JG, Meyerson LA et al (2017) Global network for invasion science: benefits, challenges and guidelines. Biol Invasions 19:1081-1096. doi:10.1007/s10530-016-13021303

Pauchard A, Nuñez MA, Raffaele E, Bustamante RO, Ledgard N, Relva MA, Simberloff D (2010) Introduced conifer invasions in South America: an update. Front Biogeogr $2: 34-36$

Pauchard A, Garcia R, Zalba S, Sarasola M, Zenni R, Ziller S, Nuñez MA (2015) Pine invasions in South America: reducing their ecological impacts through active management. In: Canning Clode J (ed) Biological invasions in changing ecosystems. De Gruyter Open Ltd, Berlin, pp 318-342

Pauchard A, Escudero A, Garcia RA, Mdl Cruz, Langdon B, Cavieres LA, Esquivel J (2016) Pine invasions in treeless environments: dispersal overruns microsite heterogeneity. Ecol Evol 6:447-459

Paul TSH, Ledgard NJ (2008) Effect of felled wilding pines on plant growth in high country grasslands. N Z Plant Prot 61:105-110

Paul TSH, Ledgard NJ (2009) Vegetation succession associated with wilding conifer removal. N Z Plant Prot 62:374-379

Pearson DE, Ortega YK, Runyon JB, Butler JL (2016) Secondary invasion: the bane of weed management. Biol Conserv 197:8-17

Peña E, Pauchard A (2001) Coníferas introducidas en áreas protegidas: un riesgo para la biodiversidad. Bosque Nativo 30:3-7

Peña E, Langdon B, Pauchard A (2007) Árboles exóticos naturalizados en el bosque nativo chileno. Bosque Nativo 40:3-7

Pringle A, Bever JD, Gardes M, Parrent JL, Rillig MC, Klironomos JN (2009) Mycorrhizal symbioses and plant invasions. Annu Rev Ecol Evol Syst 40:699-715

Procheş Ş, Wilson JRU, Richardson DM, Rejmánek M (2008) Searching for phylogenetic pattern in biological invasions. Glob Ecol Biogeogr 17:5-10

Procheş Ş, Wilson JRU, Richardson DM, Rejmánek M (2012) Native and naturalized range size in Pinus: relative importance of biogeography, introduction effort and species traits. Glob Ecol Biogeogr 21:513-523

Rejmánek M (1989) Invasibility of plant communities. In: Drake JA, Mooney HA, di Castri F, Groves RH, Kruger FJ, Rejmánek M, Williamson M (eds) Biological invasions. A global perspective. Wiley, Chichester, pp 369-388

Rejmánek M (1996) A theory of seed plant invasiveness: the first sketch. Biol Conserv 78:171-181

Rejmánek M, Richardson DM (1996) What attributes make some plant species more invasive? Ecology 6:1655-1661

Rejmánek M, Richardson DM (2013) Trees and shrubs as invasive alien species-2013 update of the global database. Divers Distrib 19:1093-1094

Rejmánek M, Richardson DM, Pyšek P (2013) Plant invasions and invasibility of plant communities. In: van der Maarel E, Franklin J (eds) Vegetation ecology. Wiley-Blackwell, Oxford, pp 387-424

Relva MA, Nunez MA, Simberloff D (2010) Introduced deer reduce native plant cover and facilitate invasion of nonnative tree species: evidence for invasional meltdown. Biol Invasions 12:303-311
Ricciardi A, Blackburn TM, Carlton JT et al (2017) Invasion science: a horizon scan of emerging challenges and opportunities. Trends Ecol Evol 32:464-474

Richardson DM (ed) (1998a) Ecology and biogeography of Pinus. Cambridge University Press, Cambridge

Richardson DM (1998b) Forestry trees as invasive aliens. Conserv Biol 12:18-26

Richardson DM (2006) Pinus: a model group for unlocking the secrets of alien plant invasions? Preslia 78:375-388

Richardson DM, Bond WJ (1991) Determinants of plant distribution: evidence from pine invasions. Am Nat 137: 639-668

Richardson DM, Higgins SI (1998) Pines as invaders in the southern hemisphere. In: Richardson DM (ed) Ecology and biogeography of Pinus. Cambridge University Press, Cambridge, pp 450-473

Richardson DM, Kluge RL (2008) Seed banks of invasive Australian Acacia species in South Africa: role in invasiveness and options for management. Perspect Plant Ecol Evol Syst 10:161-177

Richardson DM, Petit R (2005) Pines as invasive aliens: outlook on transgenic pine plantations in the Southern Hemisphere. In: Williams CG (ed) Landscapes, genomics and transgenic conifers. Springer, Dordrecht, pp 169-188

Richardson DM, Rejmánek M (2004) Conifers as invasive aliens: a global survey and predictive framework. Divers Distrib 10:321-331

Richardson DM, Rejmánek M (2011) Trees and shrubs as invasive alien species-a global review. Divers Distrib 17:788-809

Richardson DM, van Wilgen BW (1986) Effects of thirty five years of afforestation with Pinus radiata on the composition of mesic mountain fynbos near Stellenbosch. S Afr J Bot 52:309-315

Richardson DM, Cowling RM, Le Maitre DC (1990) Assessing the risk of invasive success in Pinus and Banksia in South African mountain fynbos. J Veg Sci 1:629-642

Richardson DM, Williams PA, Hobbs RJ (1994) Pine invasions in the Southern Hemisphere: determinants of spread and invadability. J Biogeogr 21:511-527

Richardson DM, Allsopp N, D'Antonio CM, Milton SJ, Rejmánek M (2000) Plant invasions - the role of mutualisms. Biol Rev 75:65-93

Richardson DM, Wilgen BW, Nuñez MA (2008) Alien conifer invasions in South America: short fuse burning? Biol Invasions 10:573-577

Roura-Pascual N, Richardson DM et al (2009) Ecology and management of alien plant invasions in South African fynbos: accommodating key complexities in objective decision making. Biol Conserv 142:1595-1604

Rundel PW, Dickie IA, Richardson DM (2014) Tree invasion into treeless areas: mechanisms and ecosystem processes. Biol Invasions 16:663-675

Sarasola M, Rusch V, Schlichter T, Ghersa C (2006) Tree conifers invasion in steppe areas and Austrocedus chilensis forests in NW Patagonia. Ecol Austral 16:143-156

Shackleton RT, Le Maitre DC, van Wilgen BW, Richardson DM (2017) Strategic planning and prioritisation for the management of a widespread invasive tree (Prosopis: mesquite) in South Africa. Ecosyst Serv. doi:10.1016/j.ecoser. 2016.11.022 (in press) 
Sharpe DM, Fields DE (1982) Integrating the effects of climate and seed fall velocities on seed dispersal by wind: a model and application. Ecol Mod 17:297-310

Siggins HW (1933) Distribution and rate of fall of conifer seeds. J Agric Res 47:119-128

Simberloff D, Relva MA, Nuñez M (2002) Gringos en el bosque: introduced tree invasion in a native Nothofagus/Austrocedrus forest. Biol Invasions 4:35-53

Simberloff D, Nuñez MA et al (2010) Spread and impact of introduced conifers in South America: lessons from other southern hemisphere regions. Austral Ecol 35:489-504

Simberloff D, Souza L, Nuñez MA et al (2012) The natives are restless, but not often and mostly when disturbed. Ecology 93:598-607

Smith SE, Read D (2008) Mycorrhizal symbiosis, 3rd edn. Elsevier, Amsterdam

Taylor KT, Maxwell BD, Pauchard A, Nuñez MA, Peltzer DA, Terwei A, Rew LJ (2016) Drivers of plant invasion vary globally: evidence from pine invasions within six ecoregions. Glob Ecol Biogeogr 25:96-106

Taylor KT, Maxwell BD, McWethy DB, Pauchard A, Nuñez MA, Whitlock C (2017) Pinus contorta invasions increase wildfire fuel loads and may create a positive feedback with fire. Ecology. doi:10.1002/ecy.1673

Urrutia J, Pauchard A, García RA (2013) Diferencias en la composición vegetal de un bosque de Araucaria araucana (Molina) K. Koch y Nothofagus antarctica (G. Forst.) Oerst. asociadas a un gradiente de invasión de Pinus contorta Douglas ex Loudon. Gayana Botánica 70:92-100

Van Rensburg J, van Wilgen BW, Richardson DM (2017) The challenges of managing invasive alien plants on private land in the Cape Floristic Region: insights from Vergelegen Wine Estate (2004-2015). Trans R Soc S Afr. doi:10. 1080/0035919X.2017.1288175

van Wilgen B (2012) Evidence, perceptions, and trade-offs associated with invasive alien plant control in the Table Mountain National Park, South Africa. Ecol Soc 17(2):23

van Wilgen BW, Richardson DM (2012) Three centuries of managing introduced conifers in South Africa: benefits, impacts, changing perceptions and conflict resolution. J Environ Manag 106:56-68

van Wilgen BW, Wannenburgh A (2016) Co-facilitating invasive species control, water conservation and poverty relief: achievements and challenges in South Africa's Working for Water programme. Curr Opin Environ Sustain 19:7-17

van Wilgen BM, Bond WJ, Richardson DM (1992) Ecosystem management. In: Cowling RM (ed) The ecology of fynbos: nutrients, fire and diversity. Oxford University Press, Cape Town, pp 345-371

van Wilgen BW, Dyer C, Hoffmann JH, Ivey P, Le Maitre DC, Moore JL, Richardson DM, Rouget M, Wannenburgh A, Wilson JRU (2011) National-scale strategic approaches for managing introduced plants: insights from Australian acacias in South Africa. Divers Distrib 17:1060-1075

van Wilgen BW, Forsyth GG, Le Maitre DC, Wannenburgh A, Kotzé JDF, van den Berg E, Henderson L (2012) An assessment of the effectiveness of a large, national-scale invasive alien plant control strategy in South Africa. Biol Conserv 148:28-38

van Wilgen BW, Carruthers J et al (2016a) Ecological research and conservation management in the Cape Floristic Region between 1945 and 2015: history, current understanding and future challenges. Trans R Soc S Afr 71:207-303

van Wilgen BW, Fill JM, Baard J, Cheney C, Forsyth AT, Kraaij T (2016b) Historical costs and projected future scenarios for the management of invasive alien plants in protected areas in the Cape Floristic Region. Biol Conserv 200: 168-177

Velarde SJ, Paul TSH, Monge J, Yao RT (2015) Cost benefit analysis of wilding conifer management in New Zealand; Part I-Important Impacts under current management. http://wildingconifers.org.nz/index.php/strategy/27-strategy/ 114-wilding-conifer-impact-study-under-current-manage ment. Accessed Feb 2017

Wardle DA, Peltzer DA (2017) Impacts of invasive biota in forest ecosystems in an aboveground-belowground context. Biol Invasions 1-16

Warren J, Christal A, Wilson F (2002) Effects of sowing and management on vegetation succession during grassland habitat restoration. Agric Ecosyst Environ 93:393-402

Wilson JRU, Gairifo C, Gibson MR et al (2011) Risk assessment, eradication, and biological control: global efforts to limit Australian acacia invasions. Divers Distrib 17: 1030-1046

Wilson JRU, Caplat P, Dickie I et al (2014) A standardized set of metrics to assess and monitor tree invasions. Biol Invasions 16:535-551

Wingfield MJ, Slippers B, Roux J et al (2001) Worldwide movement of exotic forest fungi, especially in the tropics and the southern hemisphere this article examines the impact of fungal pathogens introduced in plantation forestry. Bioscience 51:134-140

Wood JR, Dickie IA, Moeller HV, Peltzer DA, Bonner KI, Rattray G, Wilmshurst JM (2015) Novel interactions between non-native mammals and fungi facilitate establishment of invasive pines. J Ecol 103:121-129

Woodford DJ, Richardson DM, MacIsaac HJ et al (2016) Confronting the wicked problem of managing biological invasions. Neobiota 31:63-86

Yamagawa H, Ito S, Nakao T (2010) Restoration of semi-natural forest after clearcutting of conifer plantations in Japan. Landsc Ecol Eng 6:109-117

Zalba SM, Cuevas YA, Boó RM (2008) Invasion of Pinus halepensis Mill. following a wildfire in an Argentine grassland nature reserve. J Environ Manag 88:539-546

Zengeya T, Ivey P, Woodford DJ et al (2017) Managing conflict-generating invasive species in South Africa: challenges and trade-offs. Bothalia 47(2):a2160. doi:10.4102/ abc.v47i2.2160

Zenni RD, Bailey JK, Simberloff D (2014) Rapid evolution and range expansion of an invasive plant are driven by provenance-environment interactions. Ecol Lett 17:727-735 